\title{
Anti-Streptococcal activity of Brazilian Amazon Rain Forest plant extracts presents potential for preventive strategies against dental caries
}

\author{
Juliana Paola Correa da SILVA ${ }^{1}$, Adriana Lígia de CASTILHO' ${ }^{1}$, Cíntia Helena Couri SARACENI' ${ }^{1}$, Ingrit Elida Collantes \\ DÍAZ², Mateus Luís Barradas PACIENCIA², Ivana Barbosa SUFFREDINI ${ }^{1,2}$
}

\footnotetext{
1- Graduate Program in Dentistry, Vice-Dean Office for Post-Graduation and Research, Paulista University, São Paulo, Brazil

2- Center for Research in Biodiversity, Extraction Laboratory, Paulista University, São Paulo, Brazil
}

Corresponding address: Ivana Barbosa Suffredini - Centro para Pesquisa em Biodiversidade - Laboratório de Extração - Universidade Paulista - UNIP - Av. Paulista, 900, $1^{\circ}$ andar - Bela Vista - São Paulo - SP - Brazil - 01310-100 - Phone: 5511 3170-3776 - Fax: $55113170-3978$ - e-mail: ibsuffredini@yahoo.com.br

Submitted: June 17, 2013 - Modification: October 14, 2013 - Accepted: October 15, 2013

\section{ABSTRACT}

\begin{abstract}
Caries is a global public health problem, whose control requires the introduction of lowcost treatments, such as strong prevention strategies, minimally invasive techniques and chemical prevention agents. Nature plays an important role as a source of new antibacterial substances that can be used in the prevention of caries, and Brazil is the richest country in terms of biodiversity. Objective: In this study, the disk diffusion method (DDM) was used to screen over 2,000 Brazilian Amazon plant extracts against Streptococcus mutans. Material and Methods: Seventeen active plant extracts were identified and fractionated. Extracts and their fractions, obtained by liquid-liquid partition, were tested in the DDM assay and in the microdilution broth assay (MBA) to determine their minimal inhibitory concentrations (MICs) and minimal bactericidal concentrations (MBCs). The extracts were also subjected to antioxidant analysis by thin layer chromatography. Results: EB271, obtained from Casearia spruceana, showed significant activity against the bacterium in the DDM assay (20.67 $0.52 \mathrm{~mm}$ ), as did EB1129, obtained from Psychotria sp. (Rubiaceae) $(15.04 \pm 2.29 \mathrm{~mm})$. EB1493, obtained from Ipomoea alba, was the only extract to show strong activity against Streptococcus mutans $(0.08 \mathrm{mg} / \mathrm{mL}<\mathrm{MIC}<0.16 \mathrm{mg} / \mathrm{mL} ; \mathrm{MBC}=0.16$ $\mathrm{mg} / \mathrm{mL}$ ) in the MBA. Conclusions: The active extracts, discovered in the Amazon rain forest, show potential as sources of new antibacterial agents for use as chemical coadjuvants in prevention strategies to treat caries.
\end{abstract}

Keywords: Streptococcus mutans. Amazonian ecosystem. Plant extracts. Antioxidants. Anti-infective agents.

\section{INTRODUCTION}

The introduction of new non-profitable therapeutic methods related to the treatment of caries disease is a challenge for low- and middleincome countries that may have effect on children's growth and adults' general health ${ }^{16}$. Much has already been done with the introduction of new approaches, such as minimally invasive techniques ${ }^{5}$ and antibiotics ${ }^{20}$, as well as the popularization of and access to toothbrushes, toothpastes ${ }^{18}$, mouth washers and flossing materials. Good diet, combined with oral health habits, such as brushing, washing, flossing and chewing, may diminish the incidence of caries. If caries do occur and dentin is involved, chemical-mechanical removal performed according to minimally invasive techniques can be performed.

Discovering new antibacterial products that can be used as coadjuvants in caries treatment and in the composition of dentifrices may add to the efficacy of oral health programs. Nature is one of the main sources of new antimicrobial molecules. During the last two decades, natural products represented one of the main sources of new drugs approved by the Food and Drug Administration (FDA $)^{17}$. Much research has been conducted so far, and screening programs have 
been introduced in many countries, including the United States, Madagascar, Cameroon, Indonesia, China, India, and many others. In Brazil, screening programs have been well established ${ }^{1,19,27,30}$ since the Environment Ministry promulgated MP 2.186 in August 26 $6^{\text {th }}, 2001$, introducing guidelines to bioprospect the Brazilian biodiversity, which is considered to be the richest in the world and one of the least studied in terms of its pharmacological and chemical potential.

The introduction of new antibacterial compounds for use as chemical antibacterial agents in dentifrices and cements may play an important role in caries prevention and its chemical control, particularly compounds obtained from nature. Traditionally, natural products are used in dental products. For example, eugenol and some plant extracts obtained from Zizyphus joazeiro (juá), Mentha piperita (mentha) and Punica granatum (pomegranate), as well as new natural products, are frequently studied ${ }^{8}$ in the hope of introducing them into clinical practices.

Thus, our group carried out a focused search for new antimicrobial natural products active against Streptococcus involved in oral diseases. Information on the microbiological, chemical and antioxidant profiles of the active extracts will contribute to the identification and development of new antibacterial agents for use, in the near future, in prevention strategies and as chemical coadjuvant in minimal intervention techniques to treat caries.

\section{MATERIAL AND METHODS}

\section{Plant collection and extraction preparation}

Plants were collected from the Amazon and Atlantic rain forests (IBAMA license 12A/2008) according to techniques that have been previously described ${ }^{26}$. Briefly, plants were dried in an aircirculating incubator (Fanem, Diadema, SP, Brazil) at $40^{\circ} \mathrm{C}$ and were ground (Holmes, Danville, Illinois, USA). The plant powder was macerated with a 50/50 solution of dichloromethane and methanol (Synth, Diadema, SP, Brazil) for $24 \mathrm{~h}$. After that, solvents were evaporated. A second $24 \mathrm{~h}$ maceration was performed with Milli-Q water (Millipore, Diadema, SP, Brazil) before the extract was lyophilized (Virtis, Stone Ridge, NY, USA). Organic and aqueous extracts were kept at $-20^{\circ} \mathrm{C}$ until use.

\section{Extracts and standard drug preparation}

Organic extracts were solubilized in 50\% dimethylsulfoxide (DMSO50; Synth, Diadema, $\mathrm{SP}, \mathrm{Brazil)}$, and aqueous extracts were solubilized in Milli-Q water ${ }^{30}$ (Millipore, Billerica, MA, USA). Screening tests in the disk diffusion assay were performed with extracts prepared at $200 \mathrm{mg} / \mathrm{mL}$, and the selected extracts were prepared at 250 ,
$200,150,100,50,25,12.5,6.3,3.2,1.6$, and $0.8 \mathrm{mg} / \mathrm{mL}$ for testing in the microdilution broth assay (MBA). Polar and non-polar fractions derived from active extracts were prepared in DMSO50 and water, respectively, at $200 \mathrm{mg} / \mathrm{mL}$. Chlorhexidine digluconate ( $\mathrm{CHX}$; Clorexidina S, FGM, Joinville, SC, Brazil) was used as standard drug. Final concentrations of $0.12,1$ and $2 \%$ of $\mathrm{CHX}$ were used in the assays.

\section{Bacteria}

Streptococcus mutans (ATCC 25175) was obtained from Microbiologics ${ }^{\circledR}$. Bacteria were kept in a mother plaque, in the $3^{\text {rd }}$ passage, and were used freshly in the $4^{\text {th }}$ passages in all experiments. Bacteria were cultivated in a glass chamber, located inside an incubator at $36^{\circ} \mathrm{C}$, for $48 \mathrm{~h}$. Microaerophyllic conditions were obtained by adding a lit candle inside the chamber. After a period of time, the oxygen inside the chamber is consumed and the fire is extinguished, which permits the microaerophyllic environment during the assay. Bacteria were resuspended in saline solution at a concentration of 0.5 MacFarland (corresponding to $1.5 \times 10^{8} \mathrm{CFU} / \mathrm{mL}$ ) for the disk diffusion method (DDM) and at concentrations of $1 \times 10^{7}, 1 \times 10^{6}$, $1 \times 10^{5}, 1 \times 10^{4}, 1 \times 10^{3}$ and $1 \times 10^{2} \mathrm{CFU} / \mathrm{mL}$ for the microdilution broth assays (MBA) ${ }^{4}$.

\section{Culture medium}

Brain heart infusion agar blood (BHIAB; Oxoid, Hampshire, UK) was prepared according to the manufacturer's instructions, and defibrinated cattle blood was added to the agar medium to a final concentration of $5 \%$.

Brain heart infusion broth (BHIB, Oxoid, Hampshire, UK) was prepared according to the manufacturer's instructions and was used in the MBA in 96-well round bottom microplates (Costar Corning, Tewsbury, MA, USA).

\section{Disk diffusion method}

BHIAB was used as the bacterial growth medium for the disk diffusion method (DDM) ${ }^{25}$ as follows. Bacteria were suspended in saline solution at 0.5 MacFarland and inoculated on BHIAB using a sterile swab. Sterile paper disks (Cefar, São Paulo, SP, Brazil) measuring $6 \mathrm{~mm}$ in diameter and $1 \mathrm{~mm}$ in height were distributed equally over the inoculated blood agar medium. Ten $\mu \mathrm{L}$ of standard drug, extracts or fractions were deposited over the paper disks. Petri dishes (J.T.Labor; Curitiba, PR, Brazil) were kept in microaerophilic-environment chambers in incubator at $36^{\circ} \mathrm{C}$ for 48 hours. The presence of a zone of inhibition was considered a positive result independent of its diameter. Extracts that inhibited bacterial growth in this method were retested in triplicate and false positives were eliminated. 
Means were statistically compared by one-way ANOVA $(p<0.05)$ and Tukey post-test (GraphPad ${ }^{\circledR}$ Prism 5.0).

\section{Microdilution broth assay}

This technique was used to determine the minimal inhibitory concentration (MIC) and the minimal bactericidal concentration (MBC) using different concentrations of active plant extracts (final concentrations corresponding to $12.5,10,7.5$, $5,2.5,1.25,0.63,0.31,0.16,0.08$ and $0.04 \mathrm{mg} /$ $\mathrm{mL}$ ) against bacterial suspensions of $1 \times 10^{7}, 1 \times 10^{6}$, $1 \times 10^{5}, 1 \times 10^{4}, 1 \times 10^{3}$ and $1 \times 10^{2} \mathrm{CFU} / \mathrm{mL}$. Briefly, 190 $\mu \mathrm{L}$ of a bacterial suspension were added to each well of 96 -well microplates. Next, $10 \mu$ l of samples were added to the corresponding wells. Each plate was set up with a positive and negative bacterial growth control. Microplates were kept in a microaerophilic environment for $48 \mathrm{~h}$ at $36^{\circ} \mathrm{C}$.

Chromatographic techniques used in the fractionation of selected antibacterial extracts

Liquid-liquid partition

One gram of each active extract was resuspended in $12 \mathrm{~mL}$ of a methanol (MeOH, Synth, Diadema, SP, Brazil) and water solution (3:1) with the addition of chloroform $\left(\mathrm{CHCl}_{3}\right.$, Synth, Diadema, SP, Brazil) if necessary. The extract suspension was transferred to a $50 \mathrm{~mL}$ burette and washed three times with 25 $\mathrm{mL}$ of $\mathrm{CHCl}_{3}$. All three $\mathrm{CHCl}_{3}$ washes were combined and evaporated, producing the chloroform fraction $\left(\mathrm{RCHCl}_{3}\right)$. The aqueous fraction was recuperated and allowed to air dry to completely eliminate the chloroform. After that, the volume was brought up to $10 \mathrm{~mL}$ using a 1:1 mixture of methanol and water. Forty $\mathrm{mL}$ of butanol (BuOH; Synth, Diadema, São Paulo, Brazil) were added to the burette, and the aqueous fraction was also gently poured into the burette. The procedure was repeated with another $25 \mathrm{~mL}$ of $\mathrm{BuOH}$. Both previously obtained $\mathrm{BuOH}$ volumes were combined and allowed to evaporate, yielding the RBuOH fraction. Finally, the aqueous fraction $\mathrm{RH}_{2} \mathrm{O}$ was recuperated and lyophilized.

The three fractions were analyzed by thin layer chromatography (Silica Gel GF254, Merck, Darmstadt, Germany). Three solvent systems were used: hexane:ethyl acetate ( $4: 1)$, chloroform:ethyl acetate $(1: 1)$ and chloroform: ethyl acetate:methanol $(2: 2: 1)$. Thin layer plates were first developed with ultraviolet light at 254 and $366 \mathrm{~nm}$, followed by treatment with $25 \%$ sulfuric acid (Synth, Diadema, SP, Brazil) and heating 29 . Then, to determine the antioxidant properties, the thin layer plates were developed with $\beta$-carotene ${ }^{21}$ (Synth, Diadema, SP, Brazil).

\section{RESULTS}

High-throughput screening using the DDM technique was applied to more than 2,000 plant extracts against $S$. mutans and resulted in the identification of 17 active aqueous (even numbered extracts) and organic (odd numbered extracts) plant extracts that somehow inhibited bacterial growth in DDM. The botanical names and general

\begin{tabular}{|c|c|c|c|c|c|c|c|}
\hline Collect \# & Collect date & Extract & Organ & Family & Genus & Species & Author \\
\hline PSC252 & $8 / 8 / 1997$ & EB71 & Aerial organs & Boraginaceae & Cordia & sp. & \\
\hline AAO3330 & $9 / 11 / 1998$ & EB271 & Leaves & Salicaceae & Caseria & spruceana & Benth. Ex Eichler \\
\hline AAO3330 & 9/11/1998 & EB272 & Leaves & Salicaceae & Caseria & spruceana & Benth. Ex Eichler \\
\hline AAO3299 & 9/10/1998 & EB631 & Stem & Rutaceae & Zanthoxylum & compactum & $\begin{array}{c}\text { (Huber ex Albuq.) } \\
\text { P.G.Waterman }\end{array}$ \\
\hline AAO3491 & $10 / 1 / 1999$ & EB869 & Stem & Ebenaceae & Diospyros & guianensis & (Aubl.) Gurke \\
\hline AAO3580 & $25 / 02 / 00$ & EB1099 & Stem & Rubiaceae & Psychotria & sp. & \\
\hline AAO3577 & $25 / 02 / 00$ & EB1109 & Stem & Annonaceae & Annona & hypoglauca & Mart. \\
\hline AAO3543 & $24 / 02 / 00$ & EB1119 & Stem & Boraginaceae & Cordia & cf. exaltata & Lam. \\
\hline AAO3580 & $25 / 02 / 00$ & EB1129 & Aerial organs & Rubiaceae & Psychotria & sp. & \\
\hline IBS142 & $12 / 8 / 2001$ & EB1343 & Leaves & Clusiaceae & Moronobea & coccinea & Aubl. \\
\hline IBS61 & $11 / 1 / 2001$ & EB1383 & Aerial organs & Boraginaceae & Cordia & nodosa & Lam. \\
\hline IBS121 & $12 / 7 / 2001$ & EB1407 & Aerial organs & Solanaceae & Solanum & cf. lanceifolium & Jacq. \\
\hline AAO4031 & $13 / 05 / 02$ & EB1493 & Aerial organs & Convolvulaceae & Ipomoea & alba & L. \\
\hline AAO4067 & $16 / 05 / 02$ & EB1539 & Aerial organs & Salicaceae & Casearia & javitensis & H.B.K. \\
\hline MBP768 & $27 / 01 / 03$ & EB1673 & Stem & Annonaceae & Annona & hypoglauca & Mart. \\
\hline AAO3812 & $4 / 5 / 2002$ & EB1779 & Aerial organs & Smilacaceae & Smilax & $\mathrm{sp}$ & \\
\hline AAO4005 & $5 / 11 / 2002$ & EB1933 & Stem & Boraginaceae & Cordia & $\mathrm{sp}$ & \\
\hline
\end{tabular}

Figure 1- Botanical data related to the plants that originated active extracts 
collection information are displayed in Figure 1.

All 17 extracts were retested in the DDM assay. Each extract was analyzed in triplicate, and the means and standard deviations (SDs) of diameters obtained in two perpendicular measurements of each zone of inhibition were obtained in $\mathrm{mm}(\mathrm{n}=6$; $\mathrm{n}_{\text {total }}=120$ ). These results are displayed in Table 1 . Two percent $\mathrm{CHX}$ was used as a standard drug, and $50 \%$ DMSO and $100 \%$ DMSO solvents, which were used in the dilution of extracts and fractions, were also tested for antibacterial activity. According to one-way ANOVA and means comparison analysis using Tukey post-test, assuming a normal distribution for all media $\left(F_{(20,125)}=170.3\right.$; $\left.r^{2}=0.9701 ; p<0.05\right)$, EB271, obtained from the leaves of Casearia spruceana (Salicaceae, Figure 1), showed a zone of inhibition diameter (20.67 \pm 0.52 $\mathrm{mm})$ similar to that of $2 \% \mathrm{CHX}(19.28 \pm 0.73 \mathrm{~mm})$ when tested against $S$. mutans.

All 17 extracts were fractionated, and the fractions were analyzed in the DDM assay. The results of the analysis from the $\mathrm{RCHCl}_{3}$ fractions are shown in Table 1. It was observed that only the $\mathrm{RCHCl}_{3}$ and $\mathrm{RBuOH}$ fractions showed antibacterial activity. $\mathrm{CHX}$ was tested at a $2 \%$ dilution and in other dilutions commonly used in Dentistry, including $0.12 \%$ and $1 \%$ dilutions, permitting a wide range of statistical comparison for practical relevance. It was observed that none of the $\mathrm{RCHCl}_{3}$ fractions showed antibacterial activity compared to $2 \% \mathrm{CHX}(\mathrm{p}<0.05)$, which was more effective. When compared with $1 \% \mathrm{CHX}$, a chlorhexidine concentration commonly used in endodontic procedures, the $\mathrm{RCHCl}_{3}$ fractions of extracts

Table 1- Antibacterial activity observed for organic extract and its fractions diluted to $200 \mathrm{mg} / \mathrm{mL}$ against Streptococcus mutans in the disk diffusion assay in brain heart infusion agar-blood. Means and standard deviation values obtained from the growth-inhibition zone diameters are given and are expressed in millimeters ( $n=6 ;$ ntotal=120). One-way ANOVA and Tukey's post test were used to compare means (significant if $\mathrm{p}<0.05$ ). *significance is indicated as a comparison of test samples to $1 \% \mathrm{CHX}$. Antioxidant activity observed for fractions obtained from active plant extracts

\begin{tabular}{|c|c|c|c|c|c|c|c|c|c|c|}
\hline \multicolumn{6}{|c|}{ DDM Antibacterial activity } & \multicolumn{5}{|c|}{ Antioxidant activity of fractions } \\
\hline EB\# & $\begin{array}{l}\text { Organic } \\
\text { extracts }\end{array}$ & $\mathrm{RCHCl}_{3}$ & RBuOH & $\mathrm{RH}_{2} \mathrm{O}$ & RDMSO & & $\mathrm{RH}_{2} \mathrm{O}$ & RBuOH & $\mathrm{RCHCl}_{3}$ & RDMSO \\
\hline EB71 & $10.66 \pm 0.59$ & $14.39 \pm 0.37^{* *}$ & - & - & $\square$ & EB71 & - & + & - & $\square$ \\
\hline EB271 & $20.67 \pm 0.52^{*}$ & - & $13.83 \pm 0.58$ & - & $\square$ & EB271 & + & + & - & $\square$ \\
\hline EB272 & $14.65 \pm 0.40$ & - & $10.13 \pm 0.51$ & - & $\square$ & EB272 & + & + & - & $\square$ \\
\hline EB631 & $10.45 \pm 0.57$ & $11.24 \pm 0.89$ & - & - & $\square$ & EB631 & - & + & - & $\square$ \\
\hline EB869 & $14.03 \pm 0.71$ & $12.04 \pm 0.43$ & - & $\mathrm{F}$ & - & EB869 & - & - & - & - \\
\hline EB1099 & $14.03 \pm 1.23$ & $15.34 \pm 1.61^{* * *}$ & - & - & - & EB1099 & - & - & - & - \\
\hline EB1109 & $11.04 \pm 0.65$ & $15.73 \pm 0.83^{\star * *}$ & $7.97 \pm 0.44$ & - & $\square$ & EB1109 & + & - & - & $\square$ \\
\hline EB1119 & $11.39 \pm 1.18$ & - & - & - & $\square$ & EB1119 & - & - & - & $\square$ \\
\hline EB1129 & $15.04 \pm 2.29$ & $17.71 \pm 0.91^{* * *}$ & - & - & - & EB1129 & - & - & - & - \\
\hline EB1343 & $9.53 \pm 0.52$ & - & - & - & $\square$ & EB1343 & + & + & - & $\square$ \\
\hline EB1383 & $12.17 \pm 0.41$ & $12.05 \pm 0.61$ & $8.71 \pm 0.90$ & $\mathrm{~F}$ & $\square$ & EB1383 & + & - & - & $\square$ \\
\hline EB1407 & $9.51 \pm 0.68$ & - & - & - & 口 & EB1407 & - & - & - & $\square$ \\
\hline EB1493 & $8.34 \pm 1.09$ & $10.78 \pm 0.30$ & - & - & $\square$ & EB1493 & - & - & - & $\square$ \\
\hline EB1539 & $11.56 \pm 0.56$ & - & - & - & - & EB1539 & + & - & - & + \\
\hline EB1673 & $9.99 \pm 0.75$ & $10.98 \pm 0.47$ & $9.94 \pm 0.16$ & - & - & EB1673 & - & + & - & - \\
\hline EB1779 & $14.28 \pm 1.45$ & $14.84 \pm 0.87^{* * *}$ & - & - & $\square$ & EB1779 & - & - & - & $\square$ \\
\hline EB1933 & $8.44 \pm 1.42$ & - & - & - & $\square$ & EB1933 & - & + & - & $\square$ \\
\hline $\mathrm{CHX} 0.12 \%$ & 10.12 & & & & & & & & & \\
\hline $\mathrm{CH} \times 1 \%$ & 12.37 & & & & & & & & & \\
\hline $\mathrm{CH} \times 2 \%$ & $19.28 \pm 0.73$ & & & & & & & & & \\
\hline DMSO 50\% & 0 & & & & & & & & & \\
\hline DMSO $100 \%$ & 0 & & & & & & & & & \\
\hline
\end{tabular}

Caption: E\#=extract number; $\mathrm{FCHCl} 3=$ chloroform fraction; $\mathrm{FBuOH}=$ buthanol fraction; $\mathrm{FMW}=$ methanol: water fraction; FDMSO=dimethylsulfoxide; S. mut=Streptococcus mutans; S.sang=Streptococcus sanguinis, $\mathrm{CHX=chlorexidin}$ digluconate, $\mathrm{DMSO}=$ dimethylsulfoxide; $\mathrm{RCHCl}_{3}=$ chloroform fraction; $\mathrm{RBuOH}=$ buthanol fraction; $\mathrm{RH}_{2} \mathrm{O}=$ water fraction; $\mathrm{RDMSO}=$ dimethylsulfoxide fraction; $\square=$ does not exist; NT=not tested; $(-)=$ not active; $(+)=$ active 


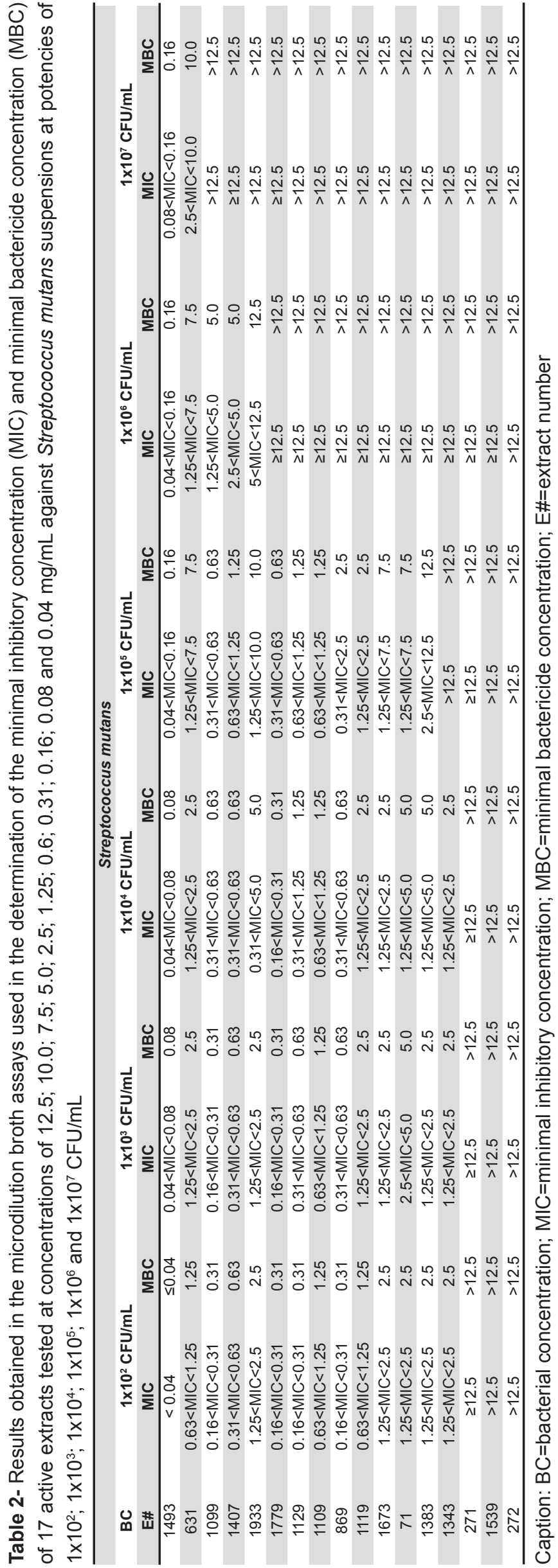

EB1129, EB1109, EB1099, EB1779 and EB71 were the most active $(p<0.05)$; however, the $\mathrm{RCHCl}_{3}$ fractions from extracts EB869, EB1383, EB631 and EB1673 showed activity similar to that observed with $1 \% \mathrm{CHX}$. The $\mathrm{RCHCl}_{3}$ fractions obtained from extracts EB1493 and EB271 did not show significant activity $(p<0.05)$. Finally, all RBuOH fractions but the one obtained from EB271 showed more significant or equal antibacterial activity compared to $0.12 \% \mathrm{CHX}$, a concentration commonly used in mouth rinses. Table 1 also shows results obtained from the analysis of the $\mathrm{RBuOH}$ fractions obtained from the active extracts. One-way ANOVA and Tukey post-test indicated that only the $\mathrm{RBuOH}$ fraction obtained from EB271 showed significant antibacterial activity $(p<0.05)$ compared with $0.12 \% \mathrm{CHX}$ and $1 \% \mathrm{CHX}$. None of the fractions showed better activity than $2 \% \mathrm{CHX}$. The $\mathrm{RBuOH}$ fractions obtained from EB272 and EB1673 showea antibacterial activity similar to $0.12 \% \mathrm{CHX}$ $(p>0.05)$. None of the other fractions had significant activity compared with the three dilutions of $\mathrm{CHX}$. Microdilution broth assay was performed on all seventeen extracts to determine the MICs and MBCs against $S$. mutans in bacterial suspensions prepared at $1 \times 10^{2}, 1 \times 10^{3}, 1 \times 10^{4}, 1 \times 10^{5}, 1 \times 10^{6}$ and $1 \times 10^{7}$ $\mathrm{CFU} / \mathrm{mL}$. Extracts were ranked (Table 2 ) according to their efficacy in bacterial growth inhibition and were considered efficient if their $\mathrm{MBC} \leq 0.31 \mathrm{mg} /$ $\mathrm{mL}$. Based on this parameter, EB1493 was the only extract that hsa significant MIC and MBC $(0.08 \mathrm{mg} /$ $\mathrm{mL}<\mathrm{MIC}<0.16 \mathrm{mg} / \mathrm{mL}$ and $M B C=0.16 \mathrm{mg} / \mathrm{mL})$ using a $S$. mutans suspension at $1 \times 10^{7} \mathrm{CFU} / \mathrm{mL}$. EB1493 was obtained from aerial organs of Ipomoea alba L. (Convolvulaceae, Figure 1). According to the Clinical Laboratory Standards Institute parameters (2003), MIC values are supposed to be obtained at bacterial concentration of $1 \times 10^{5} \mathrm{CFU} / \mathrm{mL}$. When the results are analyzed with this approach, shown in Table 2, EB1493 showed the best activity $(0.04$ $\mathrm{mg} / \mathrm{mL}<M I C<0.016 \mathrm{mg} / \mathrm{mL}$ and $\mathrm{MBC}=0.16 \mathrm{mg} /$ $\mathrm{mL})$, followed by EB1099 and EB1779 $(0.31 \mathrm{mg} /$ $\mathrm{mL}<\mathrm{MIC}<0.63 \mathrm{mg} / \mathrm{mL}$ and $M B C^{\prime} \mathrm{s}=0.63 \mathrm{mg} / \mathrm{mL}$ ) and EB869 $(0.31 \mathrm{mg} / \mathrm{mL}<M I C<0.63 \mathrm{mg} / \mathrm{mL}$ and $M B C=2.5 \mathrm{mg} / \mathrm{mL}$ ).

The antioxidant activity of all extracts and their fractions was also determined (Table 1). Antioxidant activity was found in the $\mathrm{RBuOH}$ fraction from extracts EB71, EB631, EB1673 and EB1933, in the $\mathrm{RH}_{2} \mathrm{O}$ fraction from extracts EB1109 and EB1383, in both the $\mathrm{RBuOH}$ and $\mathrm{RH}_{2} \mathrm{O}$ fractions from extracts EB271, EB272 and EB1343, and in the $\mathrm{RH}_{2} \mathrm{O}$ and RDMSO fractions from extract EB1539. Only nine of the original 17 extract fractions showed antioxidant activity, and these were concentrated mainly in the $\mathrm{RBuOH}$ and $\mathrm{RH}_{2} \mathrm{O}$ fractions. None of the FMW fractions showed antibacterial activity, and only six $\mathrm{RBuOH}$ fractions, originating from extracts EB271, 
EB272, EB631, EB1343, EB1673 and EB1933, showed both antibacterial and antioxidant activities. Finally, the RBuOH fractions obtained from extracts EB271, EB272 and EB1673 were active against $S$. mutans in the DDM assay and showed antioxidant activity.

\section{DISCUSSION}

Brazil is the richest country in the world in terms of biodiversity, and its forests can be considered a potential source of new products for use as antimicrobial agents in Dentistry. A high-throughput screening-like (HTS) approach was chosen to determine the antibacterial activity of over 2,000 plant extracts against Streptococcus mutans ${ }^{30}$. Seventeen out of 2,000 plant extracts were active against the bacteria $(0.85 \%$ yield $)$.

The extracts that were the most active in the DDM assay were EB271, obtained from the leaves of C. spruceana, and EB1129, obtained from the aerial organs of Psychotria sp. (Rubiaceae). After fractionation, the RBuOH fraction obtained from EB271 showed antibacterial activity in the DDM assay and showed the presence of antioxidant compounds. No pharmacological studies have been conducted on $C$. spruceana, but species belonging to the genus Casearia are well documented as C. sylvestris. The Clerodane diterpenoids named casearins A-F were isolated from C. sylvestris ${ }^{12}$, and, since then, many authors have demonstrated different pharmacological or biological properties related to this group of compounds, including antitumor activity ${ }^{12}$, antiulcer activity ${ }^{2}$, anti-snake ${ }^{22}$ and anti-bee ${ }^{3}$ venoms, antiplasmodial activity ${ }^{24}$, anti-inflammatory activity ${ }^{6}$ and anti-hyperlipidemic activity $^{23}$. The antibacterial activity observed in the RBuOH fraction of EB271 may indicate a possible effect related to intermediate-polar or polar substances, substantiating the antibacterial activity observed in the EB272 extract, which is an aqueous extract obtained from the same leaves used to obtain the organic extract EB271.

EB1129 also showed interesting activity in the DDM assay, and its $\mathrm{RCHCl}_{3}$ fraction showed the best activity against $S$. mutans of all the tested fractions. No antioxidant activity was observed for EB1129 or its fractions. One of the main chemical groups expected to be found in Psychotria are alkaloids from the indole ${ }^{7}$ and cyclotide ${ }^{9}$ groups. Psychoactive dimethyltryptamin was isolated from the ayahuasca Amazon plant Psychotria viridis ${ }^{28}$. Psychollatine, a monoterpene indole alkaloid, was isolated from $P$. umbellata and was verified to present an opioid-like analgesic effect, as well as antioxidant, antimutagenic, anxiolytic, antidepressant and antipsychotic activities in rodents.

Extracts that showed the best results in the
DDM assay differed from those with the best results in MBA. All of the extracts were tested at concentrations of $200 \mathrm{mg} / \mathrm{mL}$ in the DDM assay, whereas the same extracts were tested at concentrations 16 to 5,000 times more dilute in MBA. Presumably, the difference in concentration is one of the reasons for the different results, but it may also be related to the sensitivity of each assay or to the chemical composition of the extracts, as discussed elsewhere.

Only the extract EB1493, obtained from the aerial organs of Ipomoea alba L. (Convolvulaceae), showed antibacterial activity in MBA. I. alba has not been well studied in terms of its chemical constituents or pharmacological activity. The use of its latex was revealed in $1999^{11}$. Sweet potato is one of the species belonging to the Ipomoea genus. Clavine alkaloids occur in $I$. muricata ${ }^{15}$, as do ipobscurines that are macrolactam-type indole alkaloids $^{13}$, and alkaloids occur in some toxic species, as in $I$. carnea ${ }^{10}$. Other compounds, such as anthocyanins ${ }^{25}$ and polyphenolic compounds ${ }^{14}$, also occur in Ipomoea species.

Seventeen out of over 2,000 Brazilian Amazon plant extracts have been identified as potential anti-Streptococcal agents. Extracts and their fractions showed significant antibacterial activity against microorganisms involved in caries, which is one of the most important infectious diseases around the world, particularly in developing countries. These extracts represent the most important breakthrough in the development of new pharmacological weapons for Dentistry based on the biodiversity found in the Amazon rain forest.

\section{SUPPLEMENTARY MATERIAL}

Click here to view pdf.

\section{ACKNOWLEDGMENTS}

The authors would like to thank FAPESP grant \#2008/58706-8 (I.B.S.) and Paulista University for supporting expeditions to the Amazon rain forest and for supporting students (J.P.C.da S) and researchers (I.E.C.D.; M.L.B.P. and C.H.C.S.).

\section{REFERENCES}

1- Barrella GE, Suffredini IB, Ribeiro FV, Cirano FR, Pimentel SP. Evaluation of the effect of the organic extract obtained from Ipomoea alba L. on experimental periodontitis in rats. Braz Oral Res. 2012;26:158-64

2- Basile AC, Sertié JA, Panizza S, Oshiro TT, Azzolini CA. Pharmacological assay of Casearia sylvestris. I: Preventive anti-ulcer activity and toxicity of the leaf crude extract. J Ethnopharmacol. 1990;30:185-97. 
3- Borges $\mathrm{MH}$, Soares $\mathrm{AM}$, Rodrigues VM, Andrião-Escarso SH, Diniz $\mathrm{H}$, Hamaguchi A, et al. Effects of aqueous extract of Casearia sylvestris (Flacourtiaceae) on actions of snake and bee venoms and on activity of phospholipases A2. Comp Biochem Physiol B Biochem Mol Biol. 2000;127:21-30.

4- Castilho AL, Saraceni CH, Díaz IE, Paciencia ML, Suffredini IB. New trends in dentistry: plant extracts against Enterococcus faecalis. The efficacy compared to chlorhexidine. Braz Oral Res. 2013;27:109-15.

5- Ericson D. The concept of minimally invasive dentistry. Dent Update. 2007;34:9-10,12-4,17-8.

6- Esteves I, Souza IR, Rodrigues M, Cardoso LG, Santos LS, Sertie JA, et al. Gastric antiulcer and anti-inflammatory activities of the essential oil from Casearia sylvestris Sw. J Ethnopharmacol. 2005; 101:191-6.

7- Fragoso V, Nascimento NC, Moura DJ, Silva AC, Richter MF, Saffi J, et al. Antioxidant and antimutagenic properties of the monoterpene indole alkaloid psychollatine and the crude foliar extract of Psychotria umbellata Vell. Toxicol In Vitro. 2008;22:55966.

8- Furiga A, Lonvaud-Funel A, Dorignac G, Badet C. In vitro anti-bacterial and anti-adherence effects of natural polyphenolic compounds on oral bacteria. J Appl Microbiol. 2008;105:1470-6. 9- Gerlach SL, Burman R, Bohlin L, Mondal D, Göransson U. Isolation, characterization, and bioactivity of cyclotides from the Micronesian plant Psychotria leptothyrsa. J Nat Prod. 2010;73:1207-13.

10- Haraguchi M, Gorniak SL, Ikeda K, Minami Y, Kato A, Watson AA, et al. Alkaloidal components in the poisonous plant, Ipomoea carnea (Convolvulaceae). J Agric Food Chem. 2003;51:4995-5000. 11- Hosler D, Burkett SL, Tarkanian MJ. Prehistoric polymers: rubber processing in ancient Mesoamerica. Science. 1999;284:1988-91. 12- Itokawa H, Totsuka N, Takeya K, Watanabe K, Obata E. Antitumor principles from Casearia sylvestris Sw. (Flacourtiaceae), structure elucidation of new clerodane diterpenes by 2-D NMR spectroscopy. Chem Pharm Bull (Tokyo). 1988;36:1585-8.

13- Jenett-Siems K, Weigl R, Kaloga M, Schulz J, Eich E. Ipobscurines $C$ and $D$ : macrolactam-type indole alkaloids from the seeds of Ipomoea obscura. Phytochemistry. 2003;62:1257-63. 14- Kurata R, Adachi M, Yamakawa O, Yoshimoto M. Growth suppression of human cancer cells by polyphenolics from sweetpotato (Ipomoea batatas L.) leaves. J Agric Food Chem. 2007;55:185-90.

15- Maurya A, Srivastava SK: Large-scale separation of clavine alkaloids from Ipomoea muricata by $\mathrm{pH}$-zone-refining centrifugal partition chromatography. J Chromatogr B Analyt Technol Biomed Life Sci. 2009;877:1732-6.
16- Monse B, Heinrich-Weltzien R, Benzian $\mathrm{H}$, Holmgren $\mathrm{C}$, van Paslenstein Helderman W. PUFA - an index of clinical consequences of untreated dental caries. Community Dent Oral Epidemiol. 2010;38:77-82.

17- Newman DJ, Cragg DM. Natural products as sources of new drugs over the last 25 years. J Nat Prod. 2007;70:461-77.

18- Omena LM, Silva MF, Pinheiro CC, Cavalcante JC, Sampaio FC. Fluoride intake from drinking water and dentifrice by children living in a tropical area of Brazil. J Appl Oral Sci. 2006;14:382-7. 19- Ozi JM, Suffredini IB, Paciencia M, Frana SA, Dib LL. In vitro cytotoxic effects of Brazilian plant extracts on squamous cell carcinoma of the oral cavity. Braz Oral Res. 2011;25:519-25.

20- Pinheiro SL, Simionato MR, Imparato JC, Oda M. Antibacterial activity of glass-ionomer cement containing antibiotics on caries lesion microorganisms. Am J Dent. 2005;18:261-6.

21- Pratt DE, Miller EE. A flavonoid antioxidant in spanish peanuts (Arachia hypogoea). JAOCS. 1984;61:1064-7.

22- Ruppelt BM, Pereira EF, Gonçalves LC, Pereira NA. Pharmacological screening of plants recommended by folk medicine as anti-snake venom - I. Analgesic and anti-inflammatory activities. Mem Inst Oswaldo Cruz. 1991;86(Suppl. 2):203-5. 23- Schoenfelder T, Pich CT, Geremias R, Avila S, Daminelli EN, Pedrosa RC, et al. Antihyperlipidemic effect of Casearia sylvestris methanolic extract. Fitoterapia. 2008;79:465-7.

24- Simonsen HT, Nordskjold JB, Smitt UW, Nyman U, Palpu P, Joshi $\mathrm{P}$, et al. In vitro screening of Indian medicinal plants for antiplasmodial activity. J Ethnopharmacol. 2001;74:195-204.

25- Steed LE, Truong VD. Anthocyanin content, antioxidant activity, and selected physical properties of flowable purple-fleshed sweetpotato purees. J Food Sci. 2008;73:S215-21.

26- Suffredini IB, Paciencia ML, Frana SA, Varella AD, Younes RN. In vitro breast cancer cell lethality of Brazilian plant extracts. Pharmazie. 2007;62:798-800.

27- Suffredini IB, Varella AD, Younes RN. Cytotoxic molecules from natural sources: tapping the Brazilian biodiversity. Anticancer Agents Med Chem. 2006;6:367-75.

28- Tupper KW. The globalization of ayahuasca: harm reduction or benefit maximization? Int J Drug Policy. 2008;19:297-303.

29- Wagner H, Bladt S. Plant drug analysis. $2^{\text {nd }}$ ed. Berlin: Springer Verlag; 1986.

30- Younes RN, Varella AD, Suffredini IB. Discovery of new antitumoral and antibacterial drugs from Brazilian plant extracts using high throughput screening. Clinics. 2007;62:763-8. 